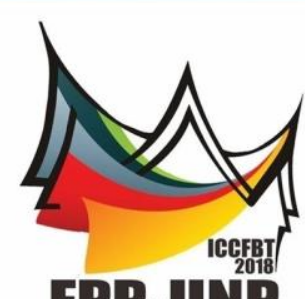

FPP-UNP

PROCEEDING

The $1^{\text {st }}$

ICGFBT 2018

INTERNATIONAL CONFERENCE ON CULINARY.

FASHION, BEAUTY AND TOURISM

Enfigfitening The World Tfurougf ICCEBT 2018

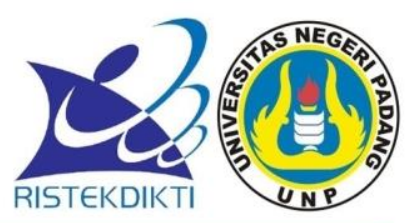

Auditorium Universitas Negeri Padang 


\section{PROCEEDING}

The $1^{\text {st }}$ International Conference on

Culinary, Fashion, Beauty, and Tourism (ICCFBT)

Theme:

“Creative Economic and Sustainable Tourism Towards Digital Globalization”

Padang, May $11^{\text {th }}-12^{\text {th }}, 2018$

Speaker:

Prof. Kaye Chon (Poly U Hongkong)

Prof. Dr. Mohd Salehuddin Mohd Zahari (University Teknologi Mara Malaysia)

Dr. Martha Tilaar (CEO Martha Tilaar Group)

Prof. David Hind (President of The Asia Pasific Institute for Event Management; Distinguished Proffesor at Chung Hua University, Taiwan and Visiting Proffesor at London Metropolitan University, UK)

\section{Fakultas Pariwisata dan Perhotelan Universitas Negeri Padang (FPP UNP)}




\section{PROCEEDING}

The $1^{\text {st }}$ International Conference on

Culinary, Fashion, Beauty, and Tourism (ICCFBT)

Theme:

"Creative Economic And Sustainable Tourism Towards Digital Globalization"

\section{Steering Committee:}

Prof. Ganefri, Ph.D

Dra. Ernawati, M.Pd, Ph.D

\section{Organizing Committee:}

Dr. Elida. M.Pd

Prof. Anni Faridah. M.Pd

Hijriyantomi Suyuthie, S.Ip, MM

Resi Yulia, SE, MM

Dra. Rahmiati, M.Pd, Ph.D

Indralena, SH. M.Pd

Dr. Yuliana, S.P, M.Si

Heru Pramudia, S.ST, M.Par

Pasaribu, SST.Par, M.Si.Par

Medris. S.Kom, M.Cio

Waryono, S.Pd, MM.Par

Dra. Ira Meirina Chair, M.Pd

Murni Astuti, S.Pd, M.Pd.T

Merita Yenita, S.Pd, M.Pd.T

Dra. Wirnelis Syarif, M.Pd

Dra. Lucy Fridayati, M.Kes

\section{CHIEF EDITOR:}

Dr. Yuliana, SP., M.Si

\section{EDITORS AND REVIEWERS:}

1. Prof. Kaye Chon - Poly U Hong Kong

2. Prof. Dr. Mohd. Salahuddin Mohd Zahari - University Teknologi Mara Malaysia

3. Prof. David Hind - Asia Pacific Institute

4. Krismadinata, ST,MT, Ph.D - Universitas Negeri Padang

5. Yohandri, M.Si., Ph. D - Universitas Negeri Padang

6. Dr. Rahadian .Z, S.Pd, M.Si - Universitas Negeri Padang

7. Ifdil, S.HI, S.Pd., M.Pd., Ph.D.Kons

8. Dra. Asmar Yulastri, M.Pd, Ph.D

9. Dr. Yenni ldrus, M.Pd 
10. Dr. Linda Rosalina, M.Biomed

11. Trisna Putra, SS, M.Sc

\section{LAYOUT EDITOR}

Cover

: Tourism and Hospitality Promotions

Content Layout

: Feri Ferdian, SST.,M.M

Hendri Azwar, S.ST Par., M.Par

Drs. Andriwifa, M.Si

\section{Published by}

Fakultas Pariwisata dan Perhotelan

Universitas Negeri Padang (FPP UNP)

Jl. Prof. Dr. Hamka Air Tawar Kota Padang

Sumatera Barat, Indonesia

Telp: 0751-7051186

Email: tourismconference@fpp.unp.ac.id

Website: tourismconference.fpp.unp.ac.id

ISBN 978-602-52249-0-4

All Right Reserved

No Part of Publication May Be Reproduce Without Written Permission of The Publisher 


\title{
TOTAL PHENOL AND ANTIOXIDANT ACTIVITY OF BROWN SEAWEED EXTRACT (Sargassum sp.)
}

\author{
Anni Faridah, Rahmi Holinesti, and Wirnelis Syarif \\ Cullinary Art Of Home Economics Department \\ Faculty Of Tourism and Hospitality Universitas Negeri Padang Indonesia \\ faridah.anni@gmail.com, r.holinesti@gmail.com, wiwique@yahoo.co.id
}

\begin{abstract}
Nirwana Beach is one of the tourist destinations in Padang West Sumatra, but almost every day littered by brown seaweed that washed up along the coast. Very unfortunate, the people around still consider this waste and do not know the usefulness and benefits. Brown seaweed has been widely studied. The content consist of alginate, fukosantin and secondary metabolites namely fucoidan. Fucoidan has been made into a supplement as antioxidant, anticoagulant and antithrombotic, antiviral, anticancer, antidiabetic, immunomodulating, antiinflammatory, antilipidemic and antifertilization. The purpose of the study was to determine the antioxidant activity of polyphenol extract from brown seaweed. The brown seaweed was extracted using aquades by heating and without heating, then the extract was evaporated with a rotary evaporator up to a volume of $50 \mathrm{ml}$ extract and then analyzed the total phenol and its antioxidant activity test. The results showed extraction with heating had higher total phenol content than without heating. The total phenol of brown seaweed extract with heating is $669.33 \mathrm{mg}$ galic acid/g, without heating $352.5 \mathrm{mg}$ of gallic acid/g and on seaweed $538.5 \mathrm{mg}$ gallic acid/g. The antioxidant activity of brown seaweed extract is very strong ie $4 \mathrm{ug} / \mathrm{ml}$ with heating and $16.6 \mathrm{ug} / \mathrm{ml}$ without heating.
\end{abstract}

KEYWORDS : brown seaweed, antioxidant, and polyphenol.

\section{INTRODUCTION}

Changes in the pattern of human life today has turned out to be one source of free radicals that play a role in the emergence of various diseases. Free radicals are molecules that are unstable and highly reactive because they contain no electrons paired in their outermost orbital so as to achievetability, radical freely react with the molecules around it to obtain an electro pair (Lim $S \mathrm{~J}$ et al, 2014). Prevention of free radical damage to the human body can be done by producing antioxidants endogenously in the system body defense. Antioxidants are defined as substances that can delay or preventing the occurrence of free-radical autoresidation reactions in lipid oxidation (Kochhar and Rossell, 1990). Antioxidants are molecules that in low concentrations can inhibit or prevent the occurrence of substrate oxidation processes (Halliwell, 2002). However, endogenous levels of antioxidants are currently unable to fight off the diseasecausing free radicals due to oxidative stress (Halliwell, 2002), requiring additional exogenous antioxidants from outside the body. While the oxidation process that occurs animal and human foods, and cosmetics can reduce its quality during the storage period. The use of antioxidants aims to prevent the occurrence of oxidation, so as not to cause poisoning or diseases caused by food and cosmetics (Guan et al., 2005; Gupta \& Abu-Ghannam, 2011).

Based on the source of the intake, exogenous antioxidants consist of natural antioxidants and synthetic antioxidants, but the safety of consuming synthetic antioxidants is not currently possible, it is necessary to find natural 
sources of antioxidants (Sunarni, 2005). One source of natural antioxidants is brown seaweed (Ye et al., 2009; Gamal, 2010). Sargassum is a type of brown seaweed from Indonesia that has potential as a natural antioxidant (Jhamandas et al., 2005) because it contains active substances such as fukoidan (Yunizal, 2003), and phenolic components (Lim et al., 2002). The type of phenolic component found in brown seaweed is phlorotanin which ranges from $0.74 \%$ to $5.06 \%$ (Samee et al., 2009). The antioxidant activity of brown seaweed can also be derived from the fukosantin pigment. The fukosantin pigment has the ability to neutralize hydroxyl radicals 13.5 times higher than $\alpha$-tocopherol as measured by chemiluminescence technique (Sachindra et al., 2007). Brown seaweed (Sargassum sp) is found in Nirwana Beach, Padang city. This study aims to determine the antioxidant activity of brown seaweed extract obtained from Nirwana Beach Padang.

\section{METHODS}

\section{Places, Materials and Tools}

This research was conducted in the laboratory of Agricultural Product Technology, Faculty of Agricultural Technology, Andalas University of Padang. The raw materials used in this research are : brown seaweed, aquadest, ethanol, methanol, $\mathrm{HCl}$, gallic acid, Folin Ciocalteu, Na2CO3, floroglusinol, $\mathrm{FeCl} 3, \mathrm{DPPH}, \mathrm{FeCl}$, ferrozine, and EDTA reagents were obtained from Sigma-Aldrich. Equipment used include oven, Erlenmeyer, hot plate stirrer (Thermolyne Nouva Stir Plate), vortex (Barnstead Thermolyne Type 37600 Mixer), centrifuge (Thermoscientific Legend Micro 17), rotary evaporator (Heidolph Instrument Laborota 4000), freeze dryer (Labconco040825210 R ), micropipet, 96-well microplate (IWAKI), silica plate (TLC Silica Gel 60 F254 E-Merck), column chromatography and High Performance Liquid Chromatography (Shimadzu SPD-6A). Extraction of brown seaweed using water solvent, then evaporated using rotary and followed by total analysis of phenol and antioxidant activity of brown seaweed extract using DPPH method.

\section{Extraction of Seaweed Chocolate}

The brown seaweed extraction procedure was carried out using Lemhadri et al. (2007).

\section{Total Phenol Analysis}

The total phenol component of brown seaweed extract was tested using methods undertaken by Matanjun et al. (2008) with acid error as standard. The standard curve is prepared with an acid solution of a galuth made by concentration dilution series of $6.25,12.5,25,50,100,200 \mu \mathrm{g} /$ $\mathrm{mL}$. Rough polyphenol extract of $5 \mathrm{mg}$ was dissolved in $1 \mathrm{~mL}$ of ethanol. Each concentration of standard solution and crude polyphenolic extract was taken $10 \mu \mathrm{l}$ and then fed into microplate 96-well. Next, into the microplate 96-well, $50 \mu \mathrm{l}$ of the Folin Ciocalteu reagent was then incubated for $5 \mathrm{~min}$. Next, added $40 \mu \mathrm{l} \mathrm{Na2CO} 37.5 \%$ and then incubated for 2 hours in a dark room with room temperature. The absorbance readings were performed at a wavelength of $750 \mathrm{~nm}$. The standard curve is made by plotting concentration $(\mu \mathrm{g} / \mathrm{mL})$ versus absorbance $(\mathrm{nm})$. The regression equation of the standard curve is $y=a x+b, R 2=c$, where $x$ is the concentration and $y$ is the absorbance. Antioxidant Activity Test 
Antioxidant activity using free radical capture method can be done quickly, easily and simply. Method of DPPH (2,2-Diphrnyl-2-picrylhydrazyl) is used to determine the ability of antioxidants to capture free radicals. Antiradical activity was characterized by a change in the color of the solution from purple to clear yellow with a decrease in absorbance at a wavelength of $517 \mathrm{~nm}$ (Soares et al, 1997).

\section{RESULTS AND DISCUSSION}

\section{Extraction}

Extraction aims to extract the active ingredient from the plant normally performed by using a solvent extraction process. Alginate and fukosantin which are thought to be the largest compositions of brown seaweed are polar molecules and consequently more soluble in polar solvents, but the extraction conditions are also a key factor in their solubility. The overall extraction conditions such as the solid-liquid ratio, incubation temperature, incubation time, solvent type and solvent concentration affect the stability and concentration of active compounds which can be from plant extracts. Methanol is the most commonly used solvent, but it is also considered to be more toxic and harmful to handle than other alcohols. Aquades, used as a solvent other than environmentally friendly, brown seaweed extract can be directly used on food products. In this research, there are two ways to produce brown seaweed extract :

1. Extraction using aquades solvent by maseration method at room temperature using 24-hour thermoshaker.

2. Extraction using aquades solvent by heating 20 minutes at $100^{\circ} \mathrm{C}$.

This treatment is based on the solubility of alginate and fukosantin compounds which are a group of polar compounds. Aquades are the safest polar compounds that can be used directly in food processing. The use of aquades is a polar solvent. From the results of experiments conducted there are some things that become obstacles in this treatment. Among other things the slow extraction process that occurs on the extraction at room temperature. This can be seen from the viscosity of the extract.

In the extraction process at the beginning time obtained extract that is not too thick so that the extraction process must be done in a long time. This may be due to the inability of the solvent aquades to enter into the sample pores at room temperature so it can not be too good to extract the alginate contained in the red dragon fruit skin sample. In addition, the dregs of the sample produced after the extraction process is obtained still feels its viscosity with the observation of the hand using the hand showed that the extraction process is less than perfect. While on extract using temperature $100 \mathrm{oC}$ for 20 minutes obtained higher viscosity. The extract has been filtered, then evaporated using rotary evaporator up to $50 \mathrm{ml}$ extract volume. The rough extract of this brown seaweed analyzed the total content of phenol, antioxidant, and antimicrobial.

\section{2. Total Phenol}

Brown seaweed (Sargassum sp) has been widely reported to contain secondary components that have certain functions such as phenol. Several studies have shown that the phenolic component of food has certain health 
effects. The phenolic component has the ability to bind to free radicals and interact with proteins. Epidemiologically, phenolic compounds exhibit several important functions such as inhibition of pathogens, triglyceride antideposition, lowering the danger of non-communicable diseases such as diabetes, cancer, stroke, anti-inflammatory, and anti-allergic (Ozcan et al., 2014).

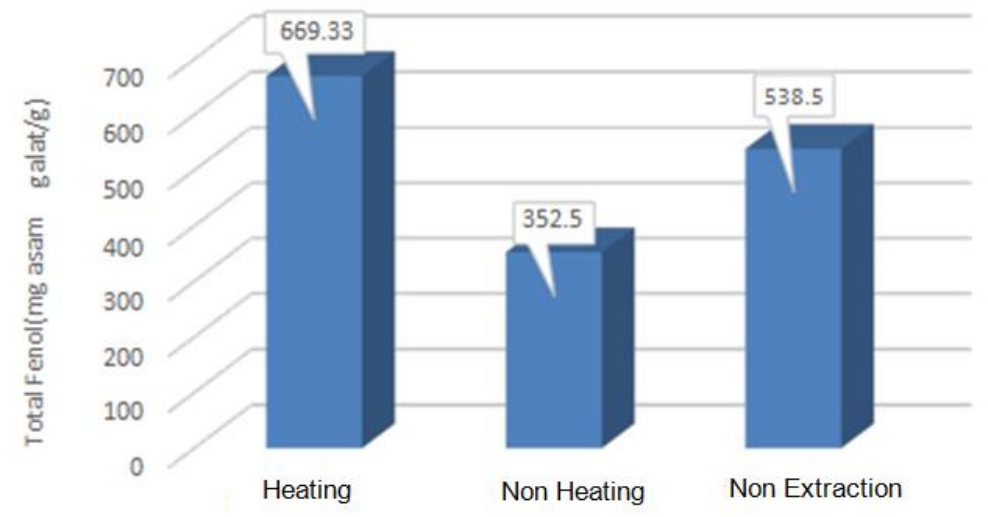

Figure 1. Total Phenol of Brown Seaweed Extract By Heating, Non Heating, and Non Extraction

The total phenol content of brown grass extract was determined using the Folin-Ciocalteu reagent method. The Folin-Ciocalteu (F-C) reagent method is the easiest method to measure total phenol in foodstuffs. This method is an expansion of the Folin Denis reagent method used in the early 19th century. The F-C reagents used in the measurements are very stable if protected from reductant and even when dissolved remain stable if protected from light. The basic mechanism applied is the oxidation or reduction reaction in which the phenolic group is oxidized and the metal ions are reduced (Agbor et al 2014). The Folin-Ciocalteu reagent method is a widely used colorimetric method for measuring the total phenol in the material. This method utilizes the rapid oxidation reaction of phenol by using alkali.

Phenol compounds in seaweed extract with heating method is much higher when compared with non heating and also higher than without extraction. From Figure 1, it can be stated that to produce a high total phenol with a water solvent, it must extracted at a temperature of $100^{\circ} \mathrm{C}$. By heating the active components especially the more phenols extracted than without heating. Figure 1 describes the total phenol content of brown seaweed extract by heating ie $669.33 \mathrm{mg}$ galic acid $/ \mathrm{g}$, without heating $352.5 \mathrm{mg}$ galic acid/g and in direct sea grass $538.5 \mathrm{mg}$ of gallic acid/g. The results also show that phenol compounds in brown seaweed are widely extracted in polar solvents, aquades. This is in accordance with the opinion of Harborne (1987) that phenol compounds tend to dissolve in polar solvents. Suradikusumah (1989) also stated that phenol compounds tend to be more water soluble because they often combine with sugar and are usually present in cell cavities.

This phenol compound is thought to have an effect on the antioxidant content in brown seaweed because Bay et al. (2017) and Chen et al. (2017) states that there is a relationship between total phenol and 
antioxidant activity where if in a material has a high concentration of phenol compounds, the antioxidant activity in the material is also high. Bay (2017) also states that phenol compounds may function as antioxidants because of their ability to negate free radicals and peroxide radicals, thereby effectively inhibiting lipid oxidation.

\section{3. Antioxidant Activity}

The antioxidant activity of the extract sample was quantitatively determined by DPPH (1,1-diphenyl-2-picrylhydrazyl), brown seaweed extract produced in the reduction or capture of DPPH radicals. This ability can be seen from the decrease in the intensity of the purple color of the DPPH solution added to the sample. Reducing the color intensity of DPPH solution can show that the reaction material test with a DPPH molecule radical to form a 1,1-diphenyl-2-picrilhidrazine yellow compound. The greater the concentration of the test material, the resulting yellow color will be stronger. Reduction of the intensity of purple color is the quantitative DPPH solution can be calculated from the decrease in absorbance of the solution. The greater the absorbance concentration of the test substance is smaller, which means that the activity of the test material in capturing more DPPH radicals. The absorbance was measured from the remaining absorbance DPPH which did not react with the test solution.

$\mathrm{DPPH}$ free radical capture activity of the sample extract can be expressed by the parameter IC50 (Inhibitor consentration 50) is the concentration of test compound causing free radical capture by $50 \%$. The value of IC50 is determined from the linear regression equation between the concentration of the test material and the average percentage of free radical capture of each concentration.



Figure 2. IC50 Content of Brown Seaweed Extract

Specifically, the compound can be said to be a very powerful antioxidant if the IC50 values are less than $50 \mathrm{ug} / \mathrm{ml}$, strong for IC50 worth $50-100 \mathrm{ug} / \mathrm{ml}$ and media for EC50 valued at 151-200 ug / ml (Bay Y. et al 2017). The antioxidant activity of the extract sample, IC50 value less than $50 \mu \mathrm{g} / \mathrm{ml}$, this shows that the extract of brown seaweed has a very strong antioxidant activity. From Figure 6 it can be seen that the antioxidant activity of brown seaweed extract with stronger heating is $4 \mu \mathrm{g} / \mathrm{ml}$ compared with no heating ie $16.6 \mu \mathrm{g} / \mathrm{ml} \mathrm{ug} / \mathrm{ml}$. The strength of antioxidants is proportional to the total content of phenol. The higher the total phenol, the stronger the antioxidant activity of the substance (Bay et 
al. 2017 and Chen et al., 2017). This strong antioxidant activity expresses the concentration of active substances in high extracts although the solvent evaporation process has not all disappeared, because the extraction is done by using a water solvent so that the evaporation process is quite difficult to remove due to the high boiling point of water.

The very high antioxidant activity of the extracts indicates that the extract has a relatively high phenolic bond, as it is well known that the antioxidant activity ability is given by the presence of phenolic groups and the presence of the conjugate double bonds present in the active compound in the extract. The more phenolic groups will make the antioxidant ability stronger (Bay et al 2017). The phenolic group is thought to be due to the high content of fucoidan in brown seaweed extract, as described by Huang C-Y et al. (2016) fucoidan extracted from sargassum has very strong antioxidant activity of $3.7 \mathrm{mg} / \mathrm{mL}$. Strong activity of antioxidant brown seaweed extract has the potential as a source of natural antioxidants to be consumed in the diet.

\section{CONCLUSION}

The total content of phenol brown seaweed extract with heating is 669.33 $\mathrm{mg}$ galic acid/g, without heating $352.5 \mathrm{mg}$ galic acid $/ \mathrm{g}$ and on seaweed $538.5 \mathrm{mg}$ of gallic acid/g. The antioxidant activity of chocolate seaweed extract is very strong ie $4 \mathrm{ug} / \mathrm{ml}$ with heating and $16.6 \mathrm{ug} / \mathrm{ml}$ without heating.

\section{ACKNOLEDGEMENTS}

Thanks to the Ministry of Research Technology and Higher Education for funding this research in BOPTN 2017 UNP.

\section{REFERENCES}

Amir Husni, Subaryono, Yudi Pranoto, Tazwir Dan Ustadi. 2012."Pengembangan Metode Ekstraksi Alginat Dari Rumput Laut Sargassum Sp Sebagai Bahan Pengental". Jurnal Agritech Vol. 32 No. 1 Hal. 1 - 6.

Andi Reskika. 2011."Evaluasi Potensi Rumput Laut Coklat( Sargassum Sp) Dan Rumput Laut Hijau (Chlorophyceae) Asal Perairan Takalar Sebagai Antibakteri Vibrio Spp". Skripsi.Makassar: Universitas Hasanuddin.

AOAC. 2012. Official Method of The Association of Official Annalytical Of Chemist. Arlington.

Ardhian E.N, Kartini Z, Hartati K. 2013. Stabilitas Fukosantin Dari Rumput Laut Cokelat (Sargassum cristaefolium) Dalam Berbagai Ph. Thpi Student Journal, Vol. 1 No. 1 pp 11-20 : Universitas Brawijaya.

Bai Y, Xu Y, Wang B, Li S, Guo F, Hua H, Zhao Y, Yu Z. 2017. Comparison of phenolic compounds, antioxidant and antidiabetic activities between selected edible beans and their different growth periods leaves Journal of Functional Foods 35: 694-702 
Chen Z, Wanga P, Weng Y, Ma Y, Gu Z, Yang R. 2017. Comparison of phenolic profiles, antioxidant capacity and relevant enzyme activity of different Chinese wheat varieties during germination. Food Bioscience 20: 159-167

Cristiane M.R, Souza D, Marques, Guerra, Silva D, Rocha, and Leite. 2006. Antioxidant Activities Of Sulphated Polysaccharides. Springer Science Business Media B: Brown and Red Seaweeds.

Fahmia A.S, Abebc M, Hosokawac M, and Miyashitac K, 2016. Lipi ds, Fatty Acids, and Fucoxanthin Content from Temperate and Tropical Brown Seaweeds, Aquatic Procedia 7:66 - 75.

Fardiaz S. 1993. Metode Analisis Mikrobiologi Pangan. Bogor: PAU-IPB.

Fawzy M.A, Gomaa M, Hifney A.F, and Khayria M. 2017. Optimization of alginate alkaline extraction technology. Sargassumlatifolium and its potential antioxidant and emulsifying properties Abdel-Gawad Carbohydrate Polymers 157:1903-1912

Fretes, Hd., Budhi, P., AB, Susanto., \& L, Limantara. 2012. Karotenoid dari Makroalgaee dan Mikroalgaee: Potensi Kesehatan Aplikasi dan Bioteknologi. J. Teknol dan Industri Pangan, 23(2): 221-228.

Gamal, E. 2010. Biological importance of marine algae. Saudi Pharmaceuthical Journal 18: 1-25.

Guan, Y., Chu, Q., Fu, L., \& Ye, J. 2005. Determination of antioxidants in cosmetics by micellar electrokinetic capillary chromatography with electrochemical detection. J. Chromatogr. A, 1074(1-2), 201-204.

Halliwell, B. (2002). Food-Derived Antioxidants: How to Evaluate Their Importance in Food and In Vivo. Dalam E. Cadenas \& L. Packer (Eds.), Handbook of Antioxidants (Edisi Kedua). Amerika Serikat: Marcel Dekker, Inc.

Handayani A, Sutarno, dan Setyawan A.D, 2004. Nutritional composition analysis of seaweed Sargassumcrassifolium J. Agardh. Surakarta: Biofarmasi 2 (2): 4552.

Harahap, Nur Asinta. 2007. Pembuatan Mie Basah dengan Penambahan Wortel (Daucus carota L. Medan. Universitas Sumatera Utara.

Hari Affandi. 2016. Pembuatan Nugget Ayam Ras Petelur Afkir. (Proyek Akhir) Padang: Universitas Negeri Padang.

Haugan, J.A., Aakemann, T., \&Liaaen-Jensen, S. 1995. Example 2: macroalgae and microalgae. In: Britton, G., Liaaen-Jensen, S., \&Pfander, H. (Eds.), Carotenoid. Volume 1A: Isolation and Analysis, pp. 215-226. Birkhauser Verlag, Basel, Switzerland.

Heo S.J, Ko S.C, Kang S.M, Kang H.S, Kim J.P, Kim S.H, Lee K.W, Cho M.G, and Jeon Y.J. 2008. Cytoprotective effect of fucoxanthin isolated from brown algae 
Sargassumsiliquastrum against $\mathrm{H} 2 \mathrm{O} 2$-induced cell damage. Eur. Food Res. Technol., 228: 145-151.

Hifney A.F, Fawzy M.A, Abdel-Gawad K.M, and Gomaa M. 2016. Industrial optimization of fucoidan extraction from Sargassum $\mathrm{sp}$ and its potential antioxidant and emulsifying activities. Food Hydrocolloids, 54: 77-88.

Hii, S. L., Pooi, Y. C., Kwan, K. W., Ching, L.W., 2010. Stability Studies of Fucoxanthin from Sargassumbinderi. Australian Journal of Basic and Applied Sciences 4(10), 4580-4584.

Huang C-H, Shu-Jing Wub, Wen-Ning Yang a, Ai-Wei Kuan a, Cheng-Yo Chen. 2016. Antioxidant activities of crude extracts of fucoidan extracted from Sargassumglaucescens by a compressional-puffing-hydrothermal extraction process. Food Chemistry 197 (2016) 1121-1129

Husni A, Subaryono, Pranoto Y, Tazwir Dan Ustadi. 2012. Pengembangan Metode Ekstraksi Alginat Dari Rumput Laut Sargassum Sp Sebagai Bahan Pengental. Jurnal Agritech Vol. 32 No. 1 Hal. 1-6.

Indriyawati N. 2015. Senyawa Fenolik dan Alginat dari Ganggang Coklat Sargassaceae Indo-Pasifik : Ekstraksi, Pemurnian, Kuantifikasi dan Aktivitas Senyawanya. Prosiding Seminar Nasional Pendidikan Biologi. Malang: 276287.

Isnani Syafarini. 2009. Karakteristik Produk Tepung Es Krim Dengan Penambahan Hidrokoloid Keraginan Dan Alginat. Skripsi. Bogor : Institut Pertanian Bogor.

Ito, N., Hirose, M., Fukushima, S., Tsuda, H., Shirai, T., \& Tatematsu, M. (1986). Studies on antioxidants: their carcinogenic and modifying effects on chemical carcinogenesis. Food Chem. Toxicol., 24(10), 1071-1082.

Jhamandas, JH, Wie MB, Harris K, Mac Tavish, and Kar S. 2005. Fucoidan inhibits cellular and neurotoxic effects of beta amyloid (A beta) in rat cholinergic basal forebrain neuron. Eur J Neuroschi. 21 (10) : 2649 - 2659.

Kochar, S.P. dan B. Rossell. 1990. Detection estimation and evaluation of antioxidants in food system. Di dalam : B.J.F. Hudson, editor. Food Antioxidants. Elvisier Applied Science. London.

Lim S.J, Mustapha W, Aida W, Maskat M.Y, Mamot S, Ropien J, and Mazita M.D. 2014. Isolation and antioxidant capacity of fucoidan from selected Malaysian seaweeds Food Hydrocolloids 42 (2014) 280-288

Lim SN, Cheung PC, Ooi VE, and Ang PO. 2002. Evaluation of antioxidative activity of extracts from a brown seaweed, Sargassum siliquastrum. J Agric Food Chem. 50 (13): 3862-3866.

Limantara, Heriyanto and E. Sadtono. 2010. Antioxidant activity study of fucoxanthin and crude pigment extracts from three species of brown algae. Proceedings of 


\section{FPP-UNP}

Natural Pigments Conference for South East Asia, Ma Chung University, \& Malang. p: 244-249.

Liu, C.L, Huang, Y.S, Hosokawa, M, Miyashita, K, and Hua, M.L. 2009. Inhibition of proliferation of a hepatoma cell line by fucoxanthin in relation to cell cycle arrest and enhanced gap junctional intercellular communication. ChemicoBiological Interactions, 182: 165-172.

Matanjun P, S. Mohamed, Mustapha NM, Muhammad K, and Ming CH. 2008. Antioxidant activities and phenolics content of eight species of seaweed from north Borneo. J. Appl Phycol. 20:367-373.

Mise, T., \& Yasumoto, T. 2011. Simultaneous Treatment of Cancer Cells Lines with the Anticancer Drug Cisplatin and the antioxidant Fucoxanthin. Br. J. Pharmacol. Toxicol., 2(3): 127-131.

Pokorny J, and Korczak, J. 2001. Preparation of natural antioxidant. In: M. Gordon (Ed.), Antioxidant In Food. CRC Press. New York, Washington D.C.

Ruperez, P., Ahrazem, O., \& Leal, J. A. (2002). Potential antioxidant capacity of sulfated polysaccharides from the edible marine brown seaweed Fucus vesiculosus. J. Agric. Food Chem., 50(4), 840-845.

Sachindra N.M, Sato E, Maeda H, Hosokawa M, Niwano Y, Kohno M, and Miyasitha K. 2007. Radical Scavenging and Singlet Oxygen Quenching Activity of Marine Carotenoid Fucoxanthin and Its Metabolites. J. Agric. Food Chem. 55: 85168522

Sachindra, N.M., Sato, E., Maeda, H., Hosokawa, M., Niwano, Y., Kohno, M., \&Miyasitha, K. 2007. Radical Scavenging and Singlet Oxygen Quenching Activity of Marine Carotenoid Fucoxanthin and Its Metabolites. J. Agric. Food Chem., 55: 8516-8522

Sunarni, T. (2005). Aktivitas antioksidan penangkap radikal bebas beberapa kecambah dari biji tanaman familia Papilionaceae. Jurnal Farmasi Indonesia 2: 53-61.

Yunizal. 2003. Minuman sari rumput laut coklat alginat. Dalam: Utomo, B.S.B., J. Basmal, Yunizal, Mulyasari, R. Peranginangin, T.D. Suryaningrum, Murdinah, dan S. Koeshendradjana. Teknologi Pemanfaatan Rumput Laut. Pusat Riset Pengolahan Produk dan Sosial Ekonomi Kelautan dan Perikanan. Jakarta.

Ye, H., Chunhong, Z., Yi, S., Xin, Z., Jun, L., Qiuhui H. dan Xiaoxiong, Z. (2009). Antioxidantactivities in vitro of ethanol extract from brown seaweedSargassum pallidum. European Food Research Technology 230: 101-109. 